Series Editor: Timothy M. Shaw, Visiting Professor, University of Massachusetts Boston, USA and Emeritus Professor, University of London, UK

The global political economy is in flux as a series of cumulative crises impacts its organization and governance. The IPE series has tracked its development in both analysis and structure over the last three decades. It has always had a concentration on the global South. Now the South increasingly challenges the North as the centre of development, also reflected in a growing number of submissions and publications on indebted Eurozone economies in Southern Europe.

An indispensable resource for scholars and researchers, the series examines a variety of capitalisms and connections by focusing on emerging economies, companies and sectors, debates and policies. It informs diverse policy communities as the established trans-Atlantic North declines and 'the rest', especially the BRICS, rise.

Titles include:

Martin Geiger, Antoine Pécoud (editors)

DISCIPLINING THE TRANSNATIONAL MOBILITY OF PEOPLE

Michael Breen

THE POLITICS OF IMF LENDING

Laura Carsten Mahrenbach

THE TRADE POLICY OF EMERGING POWERS

Strategic Choices of Brazil and India

Vassilis K. Fouskas and Constantine Dimoulas

GREECE, FINANCIALIZATION AND THE EU

The Political Economy of Debt and Destruction

Hany Besada and Shannon Kindornay (editors)

MULTILATERAL DEVELOPMENT COOPERATION IN A CHANGING GLOBAL

ORDER

Caroline Kuzemko

THE ENERGY-SECURITY CLIMATE NEXUS

Hans Löfgren and Owain David Williams (editors)

THE NEW POLITICAL ECONOMY OF PHARMACEUTICALS

Production, Innnovation and TRIPS in the Global South

Timothy Cadman (editor)

CLIMATE CHANGE AND GLOBAL POLICY REGIMES

Towards Institutional Legitimacy

Ian Hudson, Mark Hudson and Mara Fridell

FAIR TRADE, SUSTAINABILITY AND SOCIAL CHANGE

Andrés Rivarola Puntigliano and José Briceño-Ruiz (editors)

RESILIENCE OF REGIONALISM IN LATIN AMERICA AND THE CARIBBEAN

Development and Autonomy

Godfrey Baldacchino (editor)

THE POLITICAL ECONOMY OF DIVIDED ISLANDS

Unified Geographies, Multiple Polities 
Mark Findlay

CONTEMPORARY CHALLENGES IN REGULATING GLOBAL CRISES

Helen Hawthorne

LEAST DEVELOPED COUNTRIES AND THE WTO

Special Treatment in Trade

Nir Kshetri

CYBERCRIME AND CYBERSECURITY IN THE GLOBAL SOUTH

Kristian Stokke and Olle Törnquist (editors)

DEMOCRATIZATION IN THE GLOBAL SOUTH

The Importance of Transformative Politics

Jeffrey D. Wilson

GOVERNING GLOBAL PRODUCTION

Resource Networks in the Asia-Pacific Steel Industry

Also by Martin Geiger and Antoine Pécoud

THE POLITICS OF INTERNATIONAL MIGRATION MANAGEMENT

\footnotetext{
International Political Economy Series

Series Standing Order ISBN 978-0-333-71708-0 (hardcover)

Series Standing Order ISBN 978-0-333-71110-1 (paperback)

You can receive future titles in this series as they are published by placing a standing order. Please contact your bookseller or, in case of difficulty, write to us at the address below with your name and address, the title of the series and one of the ISBNs quoted above.

Customer Services Department, Macmillan Distribution Ltd, Houndmills, Basingstoke, Hampshire RG21 6XS, England
} 


\section{Disciplining the Transnational Mobility of People}

Edited by

Martin Geiger

Banting Fellow, Carleton University, Canada

and

Antoine Pécoud

Professor, University of Paris 13, France 
Editorial matter and selection (c) Martin Geiger and Antoine Pécoud 2013

All chapters @ respective authors 2013

Softcover reprint of the hardcover 1st edition 2013 978-1-137-26306-3

All rights reserved. No reproduction, copy or transmission of this publication may be made without written permission.

No portion of this publication may be reproduced, copied or transmitted save with written permission or in accordance with the provisions of the Copyright, Designs and Patents Act 1988, or under the terms of any licence permitting limited copying issued by the Copyright Licensing Agency, Saffron House, 6-10 Kirby Street, London EC1N 8TS.

Any person who does any unauthorized act in relation to this publication may be liable to criminal prosecution and civil claims for damages.

The authors have asserted their rights to be identified as the authors of this work in accordance with the Copyright, Designs and Patents Act 1988.

First published 2013 by

PALGRAVE MACMILLAN

Palgrave Macmillan in the UK is an imprint of Macmillan Publishers Limited, registered in England, company number 785998, of Houndmills, Basingstoke, Hampshire RG21 6XS.

Palgrave Macmillan in the US is a division of St Martin's Press LLC, 175 Fifth Avenue, New York, NY 10010.

Palgrave Macmillan is the global academic imprint of the above companies and has companies and representatives throughout the world.

Palgrave ${ }^{\circledR}$ and Macmillan ${ }^{\circledR}$ are registered trademarks in the United States, the United Kingdom, Europe and other countries

ISBN 978-1-349-44243-0

ISBN 978-1-137-26307-0 (eBook)

DOI $10.1057 / 9781137263070$

This book is printed on paper suitable for recycling and made from fully managed and sustained forest sources. Logging, pulping and manufacturing processes are expected to conform to the environmental regulations of the country of origin.

A catalogue record for this book is available from the British Library.

A catalog record for this book is available from the Library of Congress. 


\section{Contents}

Notes on Contributors vii

List of Abbreviations and Acronyms $\quad \mathrm{xi}$

1 Introduction: Disciplining the Transnational Mobility of People $\quad 1$ Antoine Pécoud

2 The Transformation of Migration Politics: From Migration Control to Disciplining Mobility Martin Geiger

3 A Tale of Two Tactics: Civil Society and Competing Visions of Global Migration Governance from Below Stefan Rother

4 From Individual to Migration Flow: The European Union's Management Approach and the Rule of Law Bas Schotel

5 Overflowing Borders: Smart Surveillance and the Border as a Market Device Harrison Smith

6 'Take a Chance on Me': Premediation, Technologies of Love and Marriage Migration Management Anne-Marie D'Aoust

7 To Protect and Control: Anti-Trafficking and the Duality of Disciplining Mobility Bethany Hastie

8 'Why Do They Take the Money and Not Give Visas?': The Governmentality of Consulate Offices in Cameroon

Maybritt Jill Alpes

9 Disciplining Female Migration in Argentina: Human Rights in the Time of Migration Management Tanya Basok, Nicola Piper and Victoria Simmons 
vi Contents

10 Of Berries and Seasonal Work: The Swedish Berry Industry and the Disciplining of Labour Migration from Thailand

Madeleine Eriksson and Aina Tollefsen

11 'They Don't Beat You; They Work on Your Brain': 'Regular Illegality' and the Disciplining of Rejected Asylum Seekers

Giada de Coulon

12 Voluntary Return: The Practical Failure of a Benevolent Concept Stephan Dünnwald

Index 


\section{Notes on Contributors}

Maybritt Jill Alpes is Post-Doctoral Researcher in Anthropology at the Migration Law Section at the University of Amsterdam (Netherlands) and Associate Researcher at the Center for International Studies and Research in Paris (France). Maybritt Jill holds a PhD in Anthropology from the University of Amsterdam. Her fields of interest cover the nexus between migration and development, migrant care workers, trafficking, marriage migration and the anthropology of the state. She has published on the informational context of emigration decisions in AfricanDiaspora and on migration aspirations in the face of high deportation rates in Identity. Currently she is researching dynamics of social protection and migration between France and Cameroon.

Anne-Marie D'Aoust is Assistant Professor in the Department of Political Science at the Université du Québec in Montreal (Canada). She holds a PhD in Political Science from the University of Pennsylvania. Her research stands at the crossroad of political theory and critical International Relations scholarship. Anne-Marie is currently writing a book examining marriage migration and technologies of love in Europe, Canada and the United States. Her other projects include issues of language and the sociology of the discipline of International Relations, and an investigation of 'Security and Its Publics' (in collaboration with William Walters, Carleton University, Ottawa, Canada).

Tanya Basok is Professor of Sociology in the Department of Sociology, Anthropology and Criminology at the University of Windsor (Canada). Her research focuses principally on migration and migrant rights, on how migrant "illegality" is socially produced and on how precarious migrants experience and challenge their conditions. Tanya is the author of Tomatoes and Tortillas: Mexican Transmigrant Harvesters in Canada (2002) and Social Justice, Citizenship, and Transnational Struggles (with Suzan Ilcan, 2013).

Giada de Coulon is a PhD Candidate at the University of Neuchâtel (Switzerland). In 2012, she spent one year at Carleton University (Ottawa, Canada) where she benefited from the experience of William Walters. Previously, Giada worked as a teaching assistant for four years to her supervisor Janine Dahinden (University of Neuchâtel). Giada's 
research interests include migration processes, governmentality, law implementation, militant research and ethnographic methods.

Stephan Dünnwald is a researcher at the Centre for African Studies (Centro de Estudos Africanos) at the "ISCTE" University Institute of Lisbon (Portugal), and Research Fellow at the Institute for Cultural Anthropology and European Ethnography, University of Göttingen (Germany). Stephan has been working for the Bavarian Refugee Council, and conducted research on refugees and migrants in Central and Southeastern Europe as well as in West Africa, focusing on social impacts of migration and (forced) return in countries of origin, the externalization of European migration management and bordering processes.

Madeleine Eriksson is Cultural Geographer at the Department of Geography and Economic History, Umeå University (Umeå, Sweden). Her previous research has analyzed media representations of Northern Sweden, the notion of 'internal orientalism' and the construction of 'the other' within Sweden. Her main research interests evolve around the role of class, gender, ethnicity as well as urban and rural imaginaries in the (re)production of peripheral regions and people. Madeleine is currently working in a project entitled Transnational migration to the Swedish forest berry industry, labour market deregulation and new spatial representations.

Martin Geiger is currently a Banting Fellow at Carleton University (Ottawa) and holds a PhD in Geography from the University of Bonn (Germany). He has held visiting appointments at the University of Granada (Spain), the West University of Timisoara (Romania) and the Centre for European Studies at Carleton University. Martin is Corresponding Member of the Institute for Migration Research and Intercultural Studies (IMIS), University of Osnabrück (Germany), where he worked from 2008 until 2012. He has (co-)authored and co-edited a number of publications on different aspects of cross-border mobility, development and governance. He is co-editor of the series Mobility \& Politics (Palgrave Macmillan).

Bethany Hastie is a doctoral candidate at the Institute of Comparative Law, McGill University (Montréal, Canada), an O'Brien Fellow in Human Rights and Legal Pluralism at the Centre for Human Rights and Legal Pluralism, McGill University, and a SSHRC Doctoral Fellowship recipient. She received her J.D. from the University of British Columbia (Vancouver, Canada), and her Masters in Law (LL.M.) from McGill 
University. Her research includes work on human trafficking, international migration and refugee issues.

Antoine Pécoud is Professor of Sociology at the University of Paris 13 (France). Between 2003 and 2012, he worked for UNESCO's migration program. Antoine holds a $\mathrm{PhD}$ in social and cultural anthropology from the University of Oxford. He co-edited Migration Without Borders: Essays on the Free Movement of People (2007), Migration and Human Rights: The United Nations Convention on Migrant Workers' Rights (2009), The Politics of International Migration Management (2010; paperback 2012), Migration and Climate Change (2011) and The New Politics of International Mobility: Migration Management and Its Discontents (2012).

Nicola Piper is Associate Professor in Human Rights at the University of Sydney, Australia, and Senior Research Fellow at the Arnold Bergstraesser Institute at Freiburg University, Germany. Among Nicola's latest publications are the following volumes: New Perspectives on Gender and Migration: Livelihoods, Rights, and Entitlements (2008), South-South Migration: Implications for Social Policy and Development (with Katja Hujo, 2010) and the co-authored book Critical Perspectives on Global Governance: Rights and Regulation in Governing Regimes (with Jean Grugel, 2007).

Stefan Rother is Editorial Manager of the International Quarterly for Asian Studies and Senior Researcher at the Arnold Bergstraesser Institute for Socio-Cultural Research at the University of Freiburg (Germany). Stefan holds a PhD from the University of Freiburg His research focuses on international migration, global governance, social movements, regional integration and non-/post-Western theories of international relations. He has published in Third World Quarterly, Cooperation and Conflict, European Journal of East Asian Studies, International Migration, Zeitschriftfür Politikwissenschaft and has edited a number of collective volumes.

Bas Schotel is Assistant Professor of Legal Theory at the University of Amsterdam (Netherlands). Prior to becoming a fulltime academic in 2009, Bas worked as an Attorney at Law (Stibbe Simont Monahan \& Duhot), Strategy Consultant (Booz Allen \& Hamilton) and Manager (Netherlands Authority for the Financial Markets). Bas holds a PhD in Law from Vrije Universiteit Brussel (Belgium) and a LL.M. from Columbia University, New York (USA). His key publications include On the Right of Exclusion: Law, Ethics and Immigration Policy (2012). 
Victoria Simmons is a PhD candidate in Sociology at Carleton University (Ottawa, Canada). She holds a B.A. in Development Studies from the University of Calgary (Canada) and an M.A. in Latin American Studies from Universidad Nacional Autónoma de México (UNAM). Her doctoral dissertation focuses on the securitization and humanitarianization of migration in Mexico. She has published articles, reviews, and reports in Temas de Coyuntura (2011), the Canadian Journal of Latin American and Caribbean Studies (2011), and the United Nations International Research and Training Institute for the Advancement of Women (2008).

Harrison Smith is a PhD candidate at the University of Toronto's Faculty of Information (Toronto, Canada). His masters thesis, supervised by David Murakami Wood (Queen's University, Kingston, Canada), sought to understand the role of transnational partnerships between the state and corporate sector in border and perimeter security. Harrison has recently been examining the role of consumer surveillance and identity management with geo-locative mobile environments, in order to explore larger trends within the political economy of surveillance.

Aina Tollefsen is Associate Professor in Human Geography at the Department of Geography and Economic History, Umeå University (Umeå, Sweden). Her research areas are global labour studies, economic geography and development geography. Aina has studied labour migration between Mexico and the United States and is currently working with projects on transnational migration in the Swedish forest berry industry, and the South-South migration of female domestic workers in Latin America. 


\section{List of Abbreviations and Acronyms}

$\begin{array}{ll}\text { APMM } & \text { Asia Pacific Mission for Migrants } \\ \text { AVR } & \text { Assisted Voluntary Return } \\ \text { CARAM } & \text { Coordination of Action Research on AIDS \& Mobility } \\ \text { CBC } & \text { Canadian Broadcasting Corporation } \\ \text { CBSA } & \text { Canada Border Services Agency } \\ \text { CIC } & \text { Citizenship and Immigration Canada } \\ \text { DHS } & \text { Department of Homeland Security (USA) } \\ \text { EC } & \text { European Community } \\ \text { ECRE } & \text { European Council for Refugees and Exiles } \\ \text { EEA } & \text { European Economic Area } \\ \text { ERF } & \text { European Return Fund (EU) } \\ \text { EU } & \text { European Union } \\ \text { FOM } & \text { Federal Office for Migration (Switzerland) } \\ \text { GCIM } & \text { Global Commission on International Migration } \\ \text { GCM } & \text { Global Coalition on Migration } \\ \text { GFMD } & \text { Global Forum on Migration and Development } \\ \text { GIS } & \text { Geographical Information System } \\ \text { HLD } & \text { High-Level Dialogue on Migration and Development (UN) } \\ \text { IAMR } & \text { International Assembly of Migrants and Refugees } \\ \text { ICC } & \text { International Criminal Court } \\ \text { ICMC } & \text { International Catholic Migration Commission } \\ \text { ICMPD } & \text { International Centre for Migration Policy Development } \\ \text { IGC } & \text { Intergovernmental Consultations on Migration, Asylum } \\ & \text { and Refugees } \\ \text { IGO } & \text { Intergovernmental Organization } \\ \text { ILO } & \text { International Labour Organization } \\ \text { IMA } & \text { International Migrants' Alliance } \\ \text { IMF } & \text { International Monetary Fund } \\ \text { IMIS } & \text { Institute for Migration Research and Intercultural Studies } \\ & \text { (University of Osnabrück, Germany) } \\ \text { INGO } & \text { International Nongovernmental Organization } \\ \text { IO } & \text { International Organization } \\ \text { IOM } & \text { International Organization for Migration } \\ \text { IR } & \text { International Relations } \\ & \end{array}$


MFA Migrant Forum in Asia

MRI Migrants Rights International

NATO North Atlantic Treaty Organization

NGO Nongovernmental Organization

NIROMP New International Regime for Orderly Movements of People

NNIRR National Network for Immigrant and Refugee Rights

NSTC National Science and Technology Council (USA)

NTFP Non-Timber Forest Products

OSCE Organization for Security and Cooperation in Europe

PGA People's Global Action on Migration, Development and Human Rights

RANA Return, Reception and Re-Integration of Afghan Nationals to Afghanistan

RCMP Royal Canadian Mounted Police

SBIF Swedish Forest Berry Industry Federation

UK United Kingdom

UKBA UK Border Agency

UN United Nations

UNDESA United Nations Department of Economic and Social Affairs

UNESCO United Nations Educational, Scientific and Cultural Organization

UNGIFT United Nations Global Initiative to Fight Human Trafficking

UNHCR United Nations High Commissioner for Refugees

UNIFEM United Nations Development Fund for Women

UNMIK United Nations Interim Administration Mission in Kosovo

UNODC United Nations Office on Drugs and Crime

US/USA United States/United States of America

WB World Bank

WHO World Health Organization

WIPO World Intellectual Property Organization

WSFM World Social Forum on Migration

WTO World Trade Organization 